\title{
The Analysis of Hepatopancreas Histologycal Damage in Neocallichirus karumba (Poore and Griffin) Shrimp Caused by Heavy Metal Pb Exposure in Madura Strait
}

\author{
Maria Kristiani $^{1^{*}}$, Endang Yuli Herawati ${ }^{2}$, Uun Yanuhar $^{2}$ \\ ${ }^{1}$ Master Program of Aquaculture, Faculty of Fisheries and Marine Sciences, University of Brawijaya, Malang, Indonesia \\ ${ }^{2}$ Department of Aquaculture, Faculty of Fisheries and Marine Sciences, University of Brawijaya, Malang, Indonesia
}

\begin{abstract}
Madura strait known as the second busiest shipping lanes in Indonesia. Human activities on the environment can influence the marine ecosystem derived from the household, fishery processing and capture fisheries. It can pollute coastal environments, one of which is heavy metal exposure such as $\mathrm{Cd}, \mathrm{Hg}, \mathrm{Ca}$, As and $\mathrm{Pb}$. These metals are greatly impacting the life of sea biota. The objective of this research, therefore, is to examine the hepatopancreas damage rate of shrimp Neocallichirus karumba due to the exposure of heavy metal $\mathrm{Pb}$ in Madura Strait. Method of research is by analyzing $\mathrm{Pb}$ content in water, sediment and shrimp by taking sample from 3 different stations. Hepatopancreas damage is then analyzed with SEM-EDX. Result of research indicates that at Station $\mathrm{A}, \mathrm{Pb}$ pollution in water is the biggest and counted for $0.25 \mathrm{ppm}$, while those in sediment and shrimp are $5.85 \mathrm{ppm}$ and $1.24 \mathrm{ppm}$. At Station $\mathrm{B}, \mathrm{Pb}$ pollution in water is $0.19 \mathrm{ppm}$, whereas that in sediment is $5.51 \mathrm{ppm}$, but that in shrimp is $1.04 \mathrm{ppm}$. At Station C, Pb pollution in water counts for $0.18 \mathrm{ppm}$, and in sediment, it stands for $5.5 \mathrm{ppm}$ but $0.02 \mathrm{ppm}$ for shrimp. Result of analysis against hepatopancreas damage is explained as follows. At Station A, vacuolization is $20 \%$ and $\mathrm{Pb}$ content in organ is $0.520 \mathrm{ppm}$. At Station B, the parameters are $10 \%$ and $0.196 \mathrm{ppm}$. At Station C, it includes $15 \%$ and $0.173 \mathrm{ppm}$. Organ damage is straightforwardly related to $\mathrm{Pb}$ content in water and sediment. Shrimp age is quite influential to the percentage of organ damage.
\end{abstract}

Keywords: Heavy metal $\mathrm{Pb}$ pollution, hepatopancreas organ damage, Madura Strait, N. karumba shrimp.

\section{INTRODUCTION}

Since the beginning of the Industrial Revolution, human influence has been a major force affecting marine ecosystems through processes such as global climate change and pollution [1]. Coastal environment is where land ecosystem and sea ecosystem meet, and it is greatly vulnerable to the change of water quality. Sea ecosystem degradation may be due to industrial and domestic pollutions containing chemical compounds of ionic heavy metals such as $\mathrm{Cd}, \mathrm{Hg}, \mathrm{Ca}$, $\mathrm{As}$, and $\mathrm{Pb}$. The inhabitants of the coast mostly discharge their domestic waste into the water. Fishing activity always involves gasoline. The boats moored along coast harbors in Madura Strait have its paints usually abraded [2].

Lead is rooted from the word plumbum and symbolized as $\mathrm{Pb}$ based on Scientific Language. Lead is classified into Class IV-A Metal in the periodic table of chemical substances. It has atom number (NA) of 82 with atom weight (BA) of

\footnotetext{
* Correspondence author:

Maria Kristiani

Email : krist_fishery08@ymail.com

Address : Master Program of Aquaculture, University of Brawijaya, Jl. Veteran Malang, 65145
}

207.2 [3]. Lead or $\mathrm{Pb}$ is also considered as poisonous, indestructible, and indecomposable compared to others.

The entry of $\mathrm{Pb}$ into shrimp is definitely mediated by water. It may enter into respiration channel, such as gill, or through water absorption by body surface, and possibly through foods, particles or waters dissolved by digestion system. Before toxic substance penetrates into a life creature, it must pass through a membrane before entering the cellular room. Cellular membrane's response to heavy metal presence is often in form of membrane damage or membrane permeability, and also the distorted ATP production, which in turn causing the confusion of ionic transfer system [4]. Water sample collected in 2014 from Madura Strait has $\mathrm{Pb}$ pollution rate of $0.26 \mathrm{mg} \cdot \mathrm{L}^{-1}$, and the causal factor is that Madura Strait is the second busiest sea transportation lane in Indonesia [2].

Neocallichirus karumba is a shrimp species living in the mud along the coast. This species is a digger and also filter feeder. Therefore, it easily accumulates lead through food chain and respiration channel. Further accumulation can be found in the body and hepatopancreas organ [5]. Research is aimed to examine the hepatopan- 
creas damage rate of shrimp Neocallichirus $k a-$ rumba due to the exposure of heavy metal $\mathrm{Pb}$ in Madura Strait.

\section{MATERIALS AND METHODS Study Site}

This research was conducted in the District of Bangkalan Madura Labang in September 2014. The area of sampling is densely populated areas where people relied on the catch and fish processing, ship maintenance activities. Results or residual waste processing is done on the waterfront without regard to the impact that inflicted. With an area of $35.23 \mathrm{~km}$ coastal area can produced 647 tons of fishery products. Data comprise of water samples, sediment and shrimp N. karumba collected from 3 (three) different locations (Fig. 1).

\section{Water Sampling}

Water samples were taken at the surface and bottom waters. It is meant for accumulated rate of water in the bottom and at the surface would have been different. Water samples were taken from each point using a $500 \mathrm{ml}$ bottle of mineral water which is then preserved with $1 \mathrm{ml} \mathrm{HNO} 3$ with $\mathrm{Ph}$ range 1.5 and put in a cool box and analyzed using AAS methods. Value $\mathrm{Pb}$ content in water is the average value of the sample surface and bottom.

\section{Sediment Sampling}

Sediment samples were obtained from 3point using a small shovel. Sediment samples then inserted into sample container and analyzed at the Chemical Laboratory of Mathematics and Science, University of Brawijaya to be analyzed of heavy metals $\mathrm{Pb}$.

\section{Sampling Shrimps}

The shrimp were taken by manually digging at three points location of shrimp that are in the mud of $20-30 \mathrm{~cm}$ and then looking for a major hole that shrimp can be pulled out. Phases in sampling of shrimp can be seen in Figure 2 below.

Shrimp sample is sorted based on capture location, and it is stored in box containing sea water and mud as the living media. It keeps shrimp alive which makes them ready for analysis on the heavy metal content and hepatopancreas damage in Biochemical Laboratory, Central Laboratory of Living Sciences (LSIH), University of Brawijaya.

\section{Analysis of the Pollution Source}

Analysis of pollution sources includes documentation and interviews of residents in three stations. The interview contains information and activities work of citizens which have a direct impact to the coastal environment.

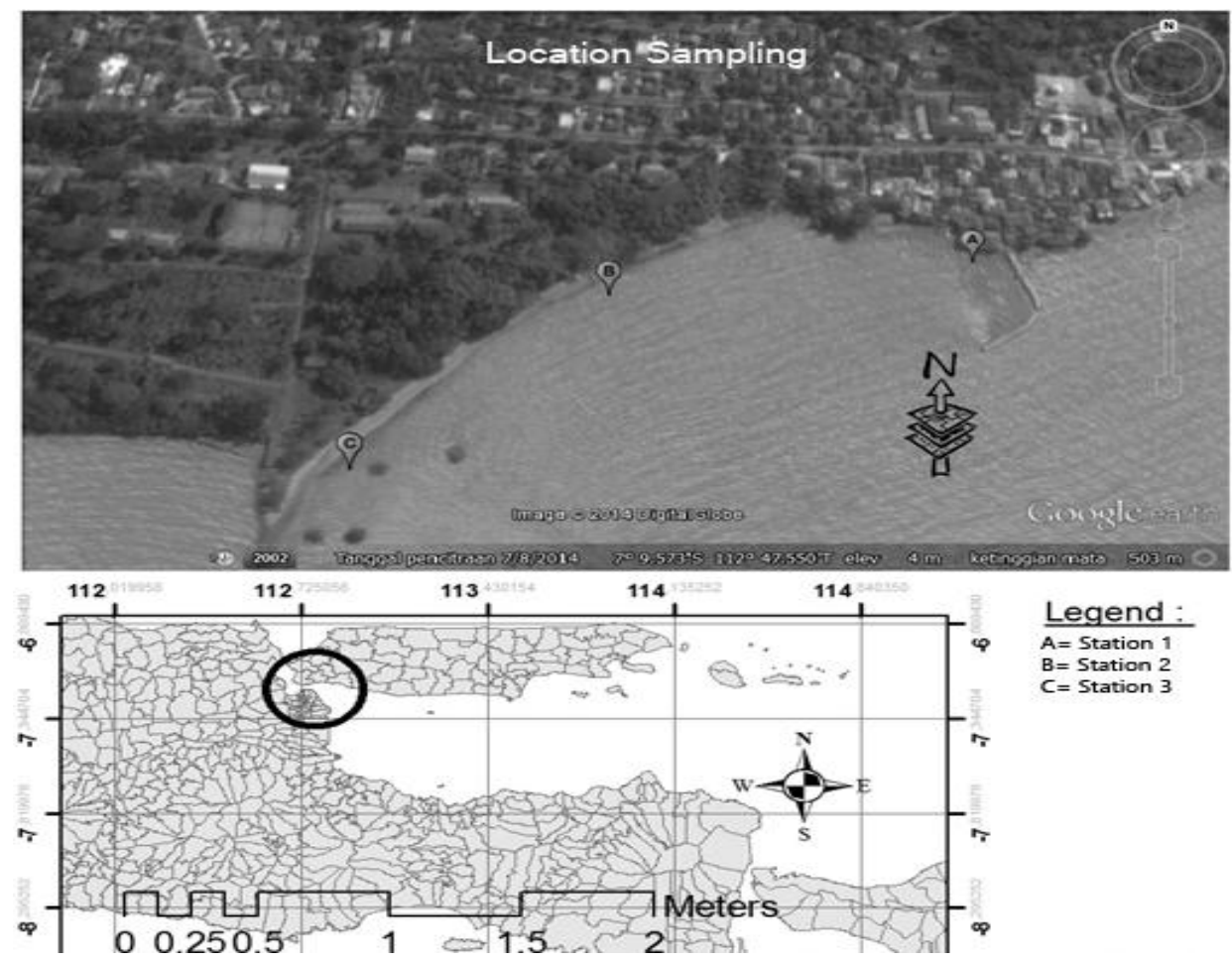

Figure 1. Research Location at the Coast of Madura Strait 


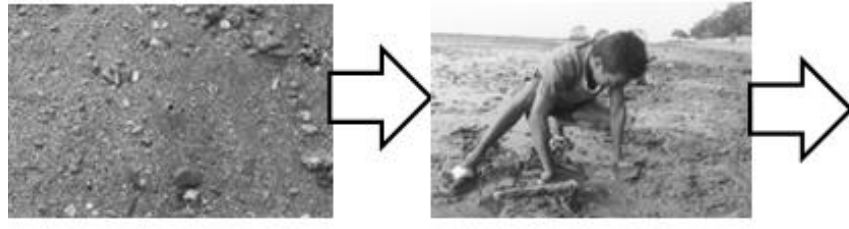

(a) (b)

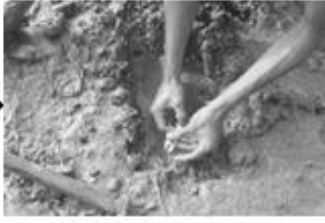

(c)

Figure 2. The Process to Collect Shrimp Sample at the Coast of Madura Strait. (a) branched holes of shrimp N. karumba, (b) excavating main holes, (c) pulling out the shrimp.

\section{Analysis}

The analysis used in this research using descriptive analysis and SEM-EDX. SEM-EDX is a Scanning Electron Spectroscopy MicroscopyEnergy Dispersive [6]. It was used to see the shrimp hepatopancreas histological damage of $N$. karumba. Hepatopancreas of $N$. Karumba shrimp then inserted into $96 \%$ alcohol and then fixated for 24 hours to get the maximum results [6].

\section{RESULT AND DISCUSSION}

The results of measuring the level of $\mathrm{Pb}$ pollution in the water, sediment, shrimp and also observation on the hepatopancreas organ can provide information on the impact of heavy metal to damage the environment and organisms that live around the site. $\mathrm{Pb}$ contents in Madura Strait can be seen in Table 1.

Table 1. Pb Content in Water, Sediment and Shrimp

\begin{tabular}{cccccc}
\hline Sta & \multicolumn{3}{c}{ Water $\left(\mathrm{mg} \cdot \mathrm{L}^{-1}\right)$} & $\begin{array}{c}\text { Sediment } \\
\text { (ppm) }\end{array}$ & $\begin{array}{c}\text { Shrimp } \\
\text { (ppm) }\end{array}$ \\
\cline { 2 - 4 } Aurface & Base & Average & 0.25 & 5.85 & 1.24 \\
B & 0.17 & 0.32 & 0,25 & 5.51 & 1.04 \\
C & 0.1 & 0.27 & 0,19 & 5.5 & 0.02 \\
\hline
\end{tabular}

\section{$\mathrm{Pb}$ Content in Water}

Household activities, periodical boat maintenance and fish catching holds important role in the location of $\mathrm{Pb}$ contents in water. The difference in value of each station can be seen in Figure 1.

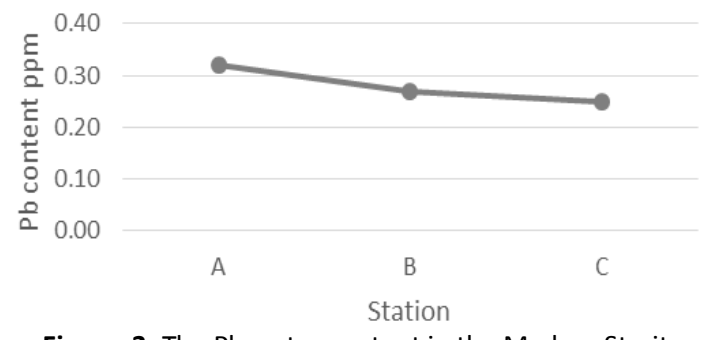

Figure 3. The $\mathrm{Pb}$ water content in the Madura Strait
Figure 3 shows difference between each station. Station $\mathrm{A}$ has the highest $\mathrm{Pb}$ content counted for $0.25 \mathrm{ppm}$ if compared to Station B with $0.19 \mathrm{ppm}$ and $\mathrm{C}$ with $0.18 \mathrm{ppm}$. As reported $\mathrm{Pb}$ content in water exceeds $0.005 \mathrm{ppm}$, and therefore, each station is considered as highly and severely polluted by $\mathrm{Pb}$ [7]. Main factors that pollute the location involve domestic activity and fishery capture. The subsistence of the majority is being fisher and processor of the haul, such as fish fumigation and fish marinating. Almost all wastes from domestic, processing and boat maintenance activities are concentrated on the coast. It may trigger the high factor of $\mathrm{Pb}$ content at certain location, especially Station $A$ that is highly populated. Abraded boat paints, trash discharge directly by the community, and fishing boat fueled with gasoline and coated with anticorrosive $\mathrm{Pb}$-loaded paints, are also increas-ing $\mathrm{Pb}$ exposure [8].

\section{$\mathrm{Pb}$ Content in Sediment}

Sediment is a product of deposition derived from land and sea brought by rain and stream. $\mathrm{Pb}$ content in sediment is displayed in Figure 4.

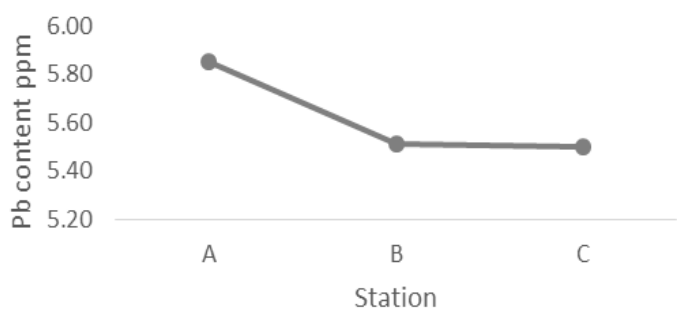

Figure 4. $\mathrm{Pb}$ Content in Sediment at Madura Strait

The increased $\mathrm{Pb}$ content in water will stimulate the increased $\mathrm{Pb}$ content in sediment due to the effect of physical, chemical and biological processes [9]. Stations A, B and C are the location of Total Suspended Solids (TSS) deposition from many locations. Madura Strait is ship lane, but it also accepts factory waste and currently, mud discharge from Lapindo Porong. Kenjeran Coast has been occupied by $60 \%$ of 
total population in Surabaya. This occupation contributes significant level of sediment waste that will be finally precipitated and carried over by the stream. The movement of stream into stations has produced small gulf, and it allows small particles to settle. This factor impacts on higher $\mathrm{Pb}$ content in sediment than in water and shrimp. The content of heavy metals in sediment increases because heavy metals in water experience dilution due to the effect of tide-ebb pattern which forces them to settle on the base of waters $[10,11]$.

\section{$\mathrm{Pb}$ Content in Shrimp}

Shrimp Neocallichirus karumba is a species that spends almost their live in the mud. This species makes two or more holes in the mud for water circulation [12]. The following is the measured $\mathrm{Pb}$ content in shrimp (Fig. 5).

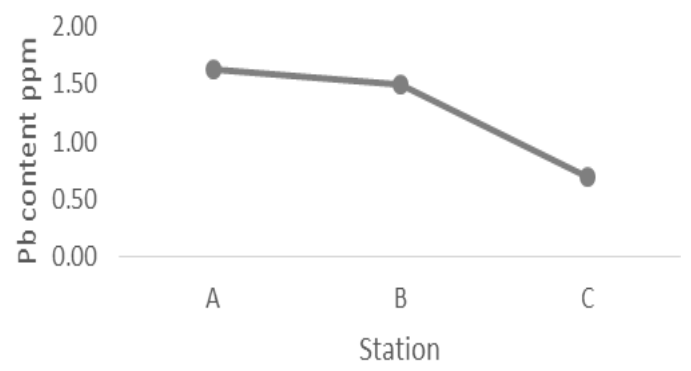

Figure 5. Pb Content in N. karumba shrimp at Madura Strait

This shrimp species is filter feeder that lives by filtering the water. This organism is sedentary, and therefore, hardly avoiding contaminants, and being highly tolerant to certain heavy metals. Therefore, shrimp can accumulate metals higher than other animals [13]. Shrimp N. karumba is consumed by immediate community because it is considered to have the ability to recover allergy, itchiness and bladder leakage among children. The impact of consuming organism with accumulated heavy metals is always felt at long-term period [14].

\section{Hepatopancreas Damage Station A}

Result of analysis with SEM-EDX against pictures, spectrums, and table of $\mathrm{Pb}$ content in hepatopancreas organ is elaborated in Figure 6. Station A is Jarat Lanjang Village with the highest pollution rate, counted for $1.24 \mathrm{ppm}$ and the category includes in the harmful organisms.

Hepatopancreas histology of shrimp $N$. Karumba is described with 500x magnification. Tubules show the presence of white spots due to
$20 \%$ vacuolization. This fact is also supported by high $\mathrm{Pb}$ content in organ for 0.520 (Fig. 7, Table 2).

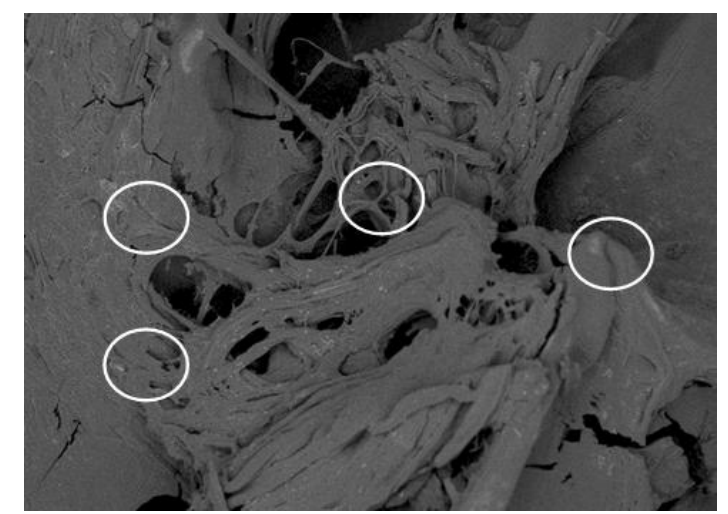

Figure 6. Hepatopancreas Organ of Shrimp N. karumba at Station A. Description: white circle shows the vacuolization and mineralization

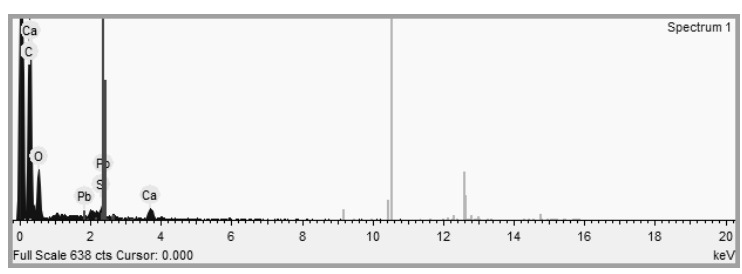

Figure 7. Edx for Chemical Substances in Hepatopancreas

Table 2. Chemical substances in hepatopancreas (\%)

\begin{tabular}{lllll}
\hline Name & $\mathbf{C}$ & $\mathbf{O}$ & $\mathbf{C a}$ & $\mathbf{P b}$ \\
\hline Spectrum 1 & 62.852 & 33.497 & 2.093 & 0.520 \\
\hline
\end{tabular}

\section{Station B}

Station B is Jungkar Village. The majority of population works as fishermen. Main pollution source in this station is coming from boat maintenance.

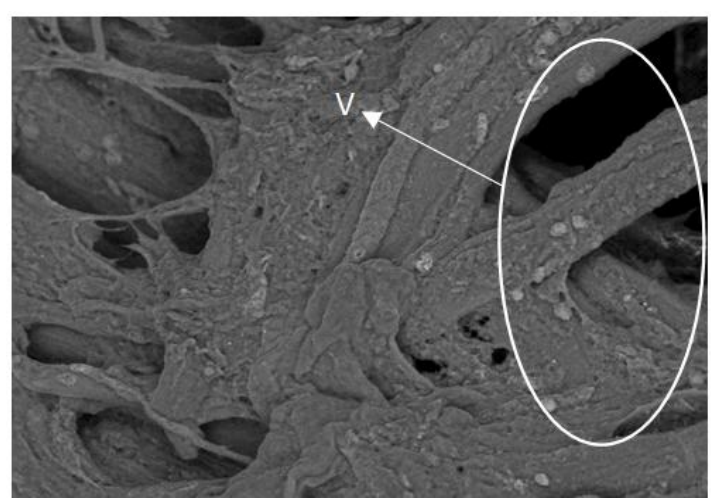

Figure 8. Hepatopancreas Organ of Shrimp N. karumba at Station B. Description: $\mathbf{V}=$ where mineralization is great and causing vacuolization

The description of hepatopancreas histology of shrimp $N$. Karumba has been obtained with $80 x$ magnification. Tubules suffer from $10 \%$ 
vacuolization. $\mathrm{Pb}$ content is is 0.196 described in the Figure 9 and Table 3.

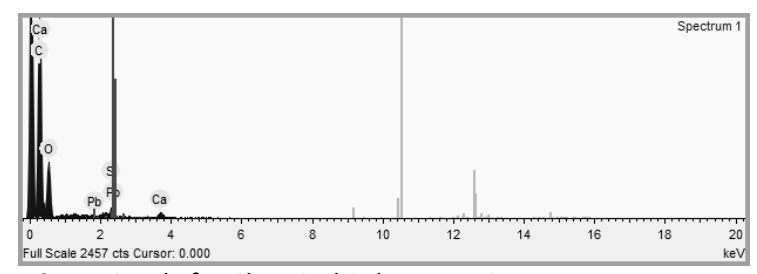

Figure 9. Edx for Chemical Substances in Hepatopancreas

Table 3. Chemical Substances in Hepatopancreas (\%)

\begin{tabular}{lllll}
\hline Name & $\mathbf{C}$ & $\mathbf{O}$ & $\mathbf{C a}$ & $\mathbf{P b}$ \\
\hline Spectrum 1 & 61.171 & 36.794 & 1.047 & 0.196 \\
\hline
\end{tabular}

\section{Station C}

Station $\mathrm{C}$ is Labinsen (Laboratorium Induk Senjata) or Main Weapon Laboratory. The site belongs to Navy base. In this station, fishery or processing activities that pollute environment are not found. $\mathrm{Pb}$ content may be still be found but it is a natural factor due to the movement of stream carrying over pollutants and TSS into the station.

The description of hepatopancreas histology of shrimp N. Karumba is magnified 80x. Tubules are subjected to $15 \%$ vacuolization. $\mathrm{Pb}$ content in Station C is 0.173 (Fig. 11, Table 4).

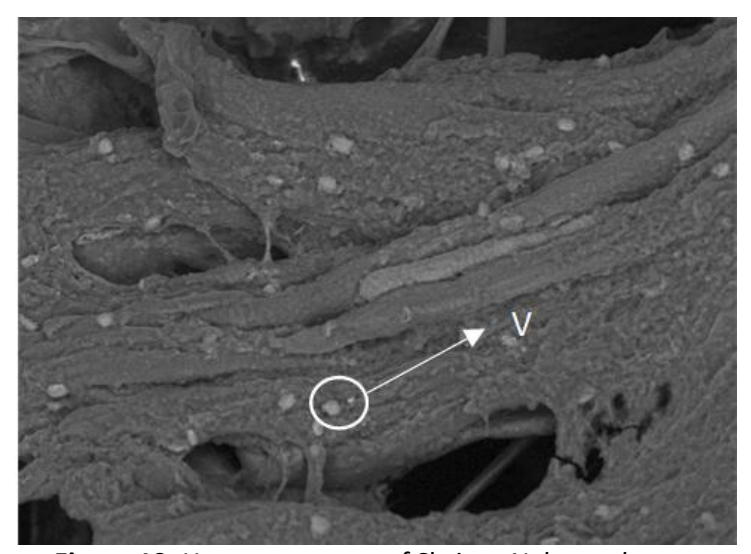

Figure 10. Hepatopancreas of Shrimp N. karumba at Station C. Description: $\mathbf{V}=$ mineralization

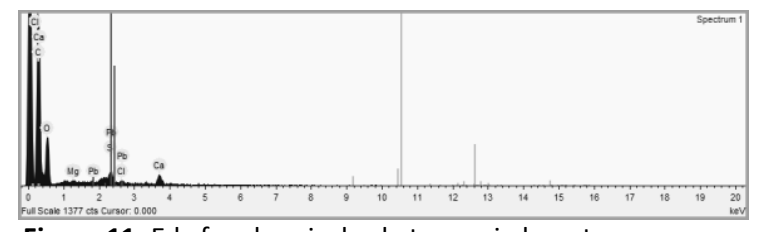

Figure 11. Edx for chemical substances in hepatopancreas

Table 4. Chemical substances in hepatopancreas (\%)

\begin{tabular}{lllll}
\hline Name & $\mathbf{C}$ & $\mathbf{O}$ & $\mathbf{C a}$ & $\mathbf{P b}$ \\
\hline Spectrum 1 & 59.938 & 35.889 & 1.921 & 0.173 \\
\hline
\end{tabular}

The highest damage rate of hepatopancreas organ is found at Station $\mathrm{A}$. The reason is that $\mathrm{Pb}$ content in water and sediment at this station is the highest if compared with that in Station B and $\mathrm{C}$. Further evidence is great quantity of white spots (due to mineralization) in different shapes in each station. It triggers what so called vacuolization [15]. Vacuolization is a common disease found in hepatopancreas organ [16]. Moreover, vacuolization, necrosis or cellular death are occurring if lead exposure is left perpetually [17].

Elongated life of shrimp, mollusc, and water animals in the mud may increase the accumulated heavy metals through perpetual food chain $[18,19]$. Metals in water column can settle into sediment [20]. It then accumulates into the body of the biota. Metals can be heaped into biota through bioaccumulation or food chain. The biological metabolism of dangerous metals may influence the growth of water organism. The accumulation of each biota may differ depending its biological characteristic (species, age and physiology) physical and chemical characteristics, and activity in each location.

\section{CONCLUSION}

Fishing activities played an important role in the level of contamination at the sites. The polluted waters may increase bioaccumulation of shrimp, which further damages hepatopancreas organ of $N$. karumba shrimp. This damage is straightforwardly related to $\mathrm{Pb}$ content in water, sediment and shrimp. It is also proved by the characteristic of shrimp as filter feeder. The ecosystem of coast environment shall be maintained because coast community often rely their subsistence on sea commodities. Shrimp $N$. karumba is highly consumed by this community without recognizing the consequence or impact of bioaccumulation.

\section{Acknowledgement}

Thanks for support and help from Central Laboratory of Living Sciences (LSIH), Laboratory of Fish Reproduction, and Laboratory in Faculty of Mathematics and Natural Sciences, University of Brawijaya, as well as Laboratory of Zoology, Indonesian Institute of Sciences (LIPI) Bogor.

\section{REFERENCES}

[1] Ivanina, A.V., I.M. Sokolova. 2015. Interactive effects of metal pollution and ocean acidifi- 
cation on physiology of marine organisms. Curr. Zool. 61(4). 653-668.

[2] Utami, 2010. Tata ruang dan penilaian dampak lingkungan industri di Bangkalan pasca pembangunan Jembatan Suramadu berdasarkan potensi daerah. Jurnal Tekhnik Industri. 11(2). 162-169.

[3] Palar, H. 2008. Pencemaran dan toksikologi logam berat. Rieneka Cipta: Jakarta.

[4] Miller., D.W. Connel. 2006. Kimia dan ekotok-sikologi pencemaran. University of Indonesia: Jakarta.

[5] Olurin, K.B., E.A.A. Olojo, G.O. Mbaka, A.T. Akindele. 2006. Histopathological responses of the gill and liver tissues of Clarias gariepinus fingerlings to the herbicide, glyphosate. Afr. J. Biotech. 5 (24). 2480-2487.

[6] Millos, M., G. Mateja. 2013. Assesment of metal pollution sources by SEM-/EDS analysis of solid particles in snow: a case study of Zerjav, Slovenia. Microsc. Microanal. (19). 1606-1619.

[7] Office of Environmental Agency. 2012. Laporan pencemaran kawasan pesisir dan laut tahun 2012. City Government of Surabaya: Surabaya.

[8] Siaka, I. M. 2008. Korelasi antara kedalaman sedimen di Pelabuhan Benoa dan konsentrasi logam berat $\mathrm{Pb}$ dan $\mathrm{Cu}$. Jurnal Kimia. 2. 61-70.

[9] Omer., M.T. Sacan, A.K. Erdem. 2009. Water quality and heavy metal monitoring in water and sediment samples of the Kucukcekmece Lagoon, Turkey (2002-2003). Environ. Monit. Assess. 151. 345-362.

[10] Rochyatun, E., Kaisuppy, M. Taufik, A.B. Rozak. 2006. Distribusi logam berat dalam air dan sedimen di perairan muara Sungai Cisadane. Makara Sains. 10(1). 35-40.

[11] Rochyatun, E., A.B. Rozak. 2007. Observasi logam berat pada sedimen di perairan Teluk Jakarta. Makara Sains. 11. 28-36.

[12] Rahman, A. 2006. Kandungan logam berat timbal $(\mathrm{Pb})$ dan kadmium (Cd) pada beberapa jenis Krustasea di Pantai Batakan dan Takisung Kabupaten Tanah Laut Kalimantan Selatan. Bioscientiae. 3. 93-101.

[13] Darmono. 2008. Lingkungan hidup dan pencemaran: hubungannya dengan toksikologi senyawa logam. University of Indonesia Press: Jakarta.

[14] WHO. 2007. Water for pharmaceutical use. In: quality assurance of pharmaceuticals: a compendium of guidelines and related materials. $2^{\text {nd }}$ Updated Ed. World Health Organization, Geneva. 170-187.

[15] Soegianto, A., N.A. Primarasti, D. Winami. 2004. Pengaruh pemberian kadmium terhadap tingkat kelangsungan hidup dan kerusakan struktur insang dan hepatopankreas pada Udang Renggang (Macrobrachium sintagense [de man]). Berkala Penelitian Hayati. (10). 59-66.

[16] Susintowati. H. Suwarno. 2014. Bioakumulasi merkuri dan struktur hepatopankreas pada Terebralia Silcata dan Nerita Argus (Molusca: Gastropoda) di kawasan bekas pengelondongan, Banyuwangi, Jawa Timur. Jurnal Manusia dan Lingkungan. 21(1). 34-40.

[17] Ersa, I.M. 2008. Gambaran histopatologi insang, usus, dan otot pada ikan mujair (Oreochromis mossambicus) di daerah Ciampea. Bogor Agricultural University: Bogor.

[18] Kim, Y., E.N. Powell, A.K.A. Ashton. 2006. Histopatology analysis. Rutgers University: Port Norris. NJ 08349.

[19] Budi, A. 2007. Pengaruh logam berat timbal $(\mathrm{Pb})$ terhadap hitopatologis hepatopankreas Udang Windu (Panaseus monodon fibricus). Thesis. Faculty of Veterinary. Airlangga University: Surabaya.

[20] Hutagalung, H.P. 1984. Logam berat dalam lingkungan laut. Pewarta Oceana. 6(1). 3738. 